\title{
Aguilar
}

\section{Notes on some Argentinian}

\section{corpses}

Cinema takes part in the tradition of rites for evoking the dead that are also rites of separation from their corpses. Once the image is formed, the corpse can be buried. Sometimes this image is a tombstone, others a death mask or a photo. Cinema provided a new possibility: filming or recording the corpse while it was alive. In this way, photography and cinema were the two most powerful instruments of immortalization (embalming) of the 20th century. This article investigates immanent and transcendent corpses in Argentinian history: Evita Perón, the desaparecidos ("missing people") of the last military dictatorship, and Pedro Eugenio Aramburu (the de facto ex-President who overthrew Perón in 1955 and was murdered by Montoneros' guerrilla organization), among others. Based on the cinematographic representations which evoke these corpses (with varying degrees of accuracy), as well as the popular expressions that accompanied them (militant songs, colloquial expressions, etc.), this text explores the transformation of a corpse, as such, to its consecration as the image of the people.

Keywords

CORPSE

REPRESENTATION

POPULAR CULTURE

ARGENTINA

FILM HISTORY

DESAPARECIDOS

Date of reception: 10/07/2018

Date of acceptance:06/05/2019

Gonzalo Aguilar (Buenos Aires, 1964) Professor of Brazilian and Portuguese Literature at the Universidad de Buenos Aires and a researcher at the National Scientific and Technical Research Council (Spanish acronym: CONICET). He is the director of the Master's Degree in Latin American Literatures at the Universidad Nacional de San Martín, and has been a guest lecturer at Stanford University, Harvard University and Universidade de São Paulo. In 2005, he received the Guggenheim fellowship. He co-wrote El cine de Leonardo Favio (1993) and Borges va al cine (2010). His books include Poesía concreta brasileña (2003); Other Worlds: New Argentine Film (2008); Episodios cosmopolitas en la cultura argentina (2009) and Más allá del pueblo. Imágenes, indicios y políticas del cine (2015). 
What is death to our entire cinematographic generation, who dived deep into the film archives, but the effect that corpses have when falling in cinema? Serge Daney

\section{Indexes}

Since its origins, cinema was linked with death, or rather, with the living dead. In olden times, there were rites that evoked the dead through images (masks, paints, costumes, mummies) and cinema is, in a way, a culminating moment in that tradition. André Bazin explained it with a metaphor: the cinematographic image is like embalming. Although many images throughout history could be used to predicate the magical nature of things, in cinema it acquires a disturbingly real indexical and ghostly character. Unlike the other methods mentioned (masks, paints, costumes, mummies), cinema is the only one which offers us the recordings of a living body in movement. Bazin talks about an "embalming of reality" and when he uses Jesus' shroud as a simile for the machine created by the Lumières, he is appealing to the sacred nature of the image, even in times of disenchantment and modernity. The appearance of dead people's lives was consigned to the screen. That is why one of the earliest myths of cinema is Dracula, an undead creature that sucks people's blood.

Therefore, the radical novelty of cinema is that it acts as a moving index which, just like photography, has been "produced under such circumstances that they were physically forced to correspond point by point to nature" (PIERCE, 1955: 106).

Cinema takes part in the tradition of rites of evoking the dead that are also the separation from their corpses. Once the image is formed, the corpse can be buried. Sometimes this image is a tombstone, others a death mask or a photo. Cinema provided a new possibility: filming or recording the corpse while it was alive. In this way, photography and cinema were the two most powerful instruments of immortalization (embalming) of the 20th century.

\section{Transcendent corpses}

Walter Benjamin writes in The Origin of German Tragic Drama that "seen from the point of view of death, the product of the corpse is life" (BENJAMIN, 1998: 218). However, it is possible that this corpse survives, mystified or with a more powerful presence than the ones alive. In Argentinian history, there are countless corpses that have lived on. They accompany us in images that show them in their moment of glory (or simply alive), and which cause them to endure in their sacred or re-enchanted state. Eva Perón, Che Guevara, the photos of the faces of the 30,000 desaparecidos ("missing people") 1 . Emblematic phrases reveal the power of these dead people: "Ever onward to victory", "divine presence", "I know you will reclaim my name and carry it like a flag to victory", "they took them away alive, we want them returned alive". These are corpses that impose a transcendental plane. They represent attempts to erase the boundary line between life and death, or to challenge what's alive as not being sufficiently alive if it doesn't possess that capacity for dedication and rebellion. Life is no longer contemplated from the corpse (as Benjamin says) but from the Revolution and its historical purpose in a general epiphany. They are the bodies of the community, the bodies that stopped being corpses to live on in images, forever.

In the case of Che Guevara, his corpse lying on a stretcher in Bolivia was associated with the figure of Christ, and travelled across the world. The Hour of the Furnaces (La hora de los hornos, Fernando E. Solanas 
and Octavio Getino, 1968) used

this image as a way to encourage liberation movements: the death of the revolutionary wasn't the testimony of a defeat but another milestone in the battle ${ }^{2}$. The faciality of Guevara's figure succeeded in surpassing death and establishing him as an emblematic figure for the battles that have taken place since his death. However, in the case of the desaparecidos, such faciality is impossible, and is multiplied on the banners that people carry on protest marches. In the face of any kind of political immortalization, the military implemented a strategy that prevented figuration. ${ }^{3}$ What to do, then, with the corpses?

In Argentina, Peronism (being the movement that most emphatically represents the people and the popular) carried out a consistent policy to provide certain corpses with a transcendent quality. Both at state level, when they were in government between 1946 and 1955, and then from a standpoint of resistance, after the government fell in 1955. In his testimonial volume Operation Massacre (Operación masacre) of 1957, Rodolfo Walsh wrote about the executions by firing squad carried out by the dictatorial government of the selfdenominated Revolución Libertadora ("Liberating Revolution") in Tristán Suárez: "one of the executed men is alive". In the film adaptation that was made in 1973, the film opens with this "executed man". His paradoxical status fits in with all the aspirations of the Peronist resistance: opposition to power, evidence of state repression, the power of the popular struggle, and the choice between nation or death (i.e., dying for one's nation is life). The counterpart of this corpse is Pedro Eugenio Aramburu, one of the key protagonists in Perón's fall and the man responsible for the firing squad executions. A popular song that "went viral" in the early 1970s, after he was shot by Montoneros' guerrilla organization, clearly shows that he is a lonely corpse, demystified or disenchanted before the return of the deaths of the popular leaders or fighters:

"Con los huesos de Aramburu

Vamo'a hacer una escalera

Pa que baje del cielo

Nuestra Evita Montonera"4

[ENG] "With Armaburu's bones We are going to make a staircase So that our Evita Montonera Comes down from heaven"

The story of Eva Perón's corpse is well-known: she died in 1952 and was embalmed by Dr Pedro Ara, using a novel technique. After the coup d'état of 1955, the corpse was kidnapped and embarked on a journey via various military institutions until finally the kidnappers secretly took her to Italy. In the early 1970s, the body was recovered; it had been slashed and despoiled". The short story "That Woman" by Rodolfo Walsh ("Esa mujer", 1965), the novel Santa Evita by Tomás Eloy Martínez (1995) and the films Evita: The Unquiet Grave (Evita la tumba sin paz, Tristan Bauer, 1997), Eva Doesn't Sleep (Eva no duerme, Pablo Agüero 2017) and Eva from Argentina (Eva de la Argentina, María Seoane, 2011) all revolve around the kidnapping of the body 6 .

Why was so much fury shown towards Evita's corpse? Because she wasn't completely dead, because she could come back anytime as a ghost that could bring down the military government. The Peronism embalming technique was an immortality policy and, in the form of Evita's body, it had been successful. It had removed the body from the organic cycle and had turned it into a sacred myth. But Evita's 
embalmed corpse was so powerful that when Peronism was toppled by a military coup, the corpse was kidnapped, despoiled and hidden away.

\section{Embalming}

Eva Perón died on June 26th 1952. As the official message, broadcast by radio and the newly-arrived television said: "at 20:25 Eva Perón, Spiritual Leader of the Nation, entered into immortality". The embalming policy (or rather, immortalization policy) was immediate. However, it is not the only strategy that can be attributed to Peronism. A little before Evita's death, on June 3rd of that same year, one of the films that, over time, would become a classic in Argentinian cinema was released: Dark River (Las aguas bajan turbias, 1952) by Hugo del Carril. A renowned advocate of the movement (he also sang the "Peronist March"), his film met with great opposition in some sectors of the government, particularly from the powerful Raúl Alejandro Apold, the Undersecretary of Press and Broadcasting. Del Carril had to make some changes for it to be accepted and, once released, it was not given any official support. There has been much talk of a personal feud between Apold and Hugo del Carril, but without a doubt, the conflict around the film had other causes. A mixture of melodrama, political preaching and neorealism, the film distanced itself from the dominant cinema that was based on conventional genres and stories that avoided any direct references. The fact that it was based on a novel by an imprisoned communist writer (Alfredo Varela) was further reason for this pressure. Though in fact, Varela doesn't appear in the credits. There is another reason that probably didn't have any conscious influence, but the way the corpses are presented in Dark River marks a difference with the prevailing discourse and its immortalization policy. Instead of embalming, Dark River portrays empty corpses.

The story begins with a voice-over (the same type as used by official news broadcasts of the time) that warns us that the story that follows happened "years ago, a few years ago". The image then moves from the beautiful landscapes of the Mesopotamian estuaries (in what seems to be a tourism promotion short) to the corpses that are dragged along by the river, and which come from the green hell of the mate plantations. Unlike the embalmed corpses whose eyes are closed and skin is smooth, the corpses that are washed along by the river in Dark River have hollow eyes and putrefied skin. They don't resemble a monument and they're anonymous ("no face, no name, no family", as the narrator says). They aren't motionless and unalterable, they move with the flow of the river, decomposing. They are organic corpses; that is, affected by time. Mortal corpses. Closer to Heraclitus than to Parmenides, they are "floating corpses".

The most important aspect of this comparison (embalmed corpse/ decomposing corpse) is that while the former signifies an immortality policy which, by association, also signifies a perpetuation of power (as in the case of Lenin, whose embalmed body is there for future generations to worship), the latter signifies a permanent struggle, working to give meaning to these corpses and to provide them with a certain direction. This is what happens in the film when the workers at the mate plantations discover the power of a trade union and rise up against the bosses ("blood fertilizes like a seed", we hear at the end of the film). At the height of the Peronist government, Hugo del Carril opposes state immortalization policies with the existence of corpses that cannot rest, that have no deathbed, and need to be redeemed.

It is no coincidence that the most important requirement made by the 
Peronist government to a Peronist film was that a prologue should be added to clarify that what happened with the corpses was something from the past, "years ago, a few years ago". In any case, these corpses never cease to pass by, float or sink. The embalming policy imagines an out-of-time state which history comes along to frustrate, again and again.

\section{Immanence and imminence}

The indexical nature of the image also exists in language. According to Charles Sanders Peirce, "a proper name, personal demonstrative, or relative pronoun" are indexes (PEIRCE 1955: 108). But what happens when that corpse doesn't have a proper name, something that is not a rare occurrence in Latin America? What happens when it's a stripped, torn-topieces, vanished, or - to use a term with great historical meaning - a desaparecido ("missing") corpse? In short, what happens when the proper name can't be used or designate a corpse that's there? Néstor Perlongher has offered a poetic answer in his text "Corpses" ("Cadáveres") via a verb: "there are" ("hay").

"En el campo

En el campo

En la casa

En la caza

Ahí

Hay Cadáveres

En el decaer de esta escritura

En el borroneo de esas inscripciones

En el difuminar de estas leyendas

En las conversaciones de lesbianas que se muestran la marca de la liga,

En ese puño elástico, Hay Cadáveres"
[ENG] "In the country

In the country

In the house

In the hunt

There

There are Corpses

In the decline of this writing

In the smudging of these inscriptions

In the blurring of these legends

In conversations of lesbians who show surrender marks to each other,

In that elastic cuff,

There are Corpses" (2002: 462463)

The "there are" is the presence that pushes up from below, the imposing force, the body which, despite being dead, is there, undisturbed and disturbing us. "Corpses", a poem written between 1982 and 1983, was published in the first issue of the magazine Diario de poesía (April 1984) in the context of the debate over the neo-Baroque or, in its Río de Plata version, the neobarroso. Benjamin's phrase becomes revealing: the corpse lost all chance of redemption, the "divine presence" only comes back as irony or insufficiency.

“En lo preciso de esta ausencia

En lo que raya esa palabra

En su divina presencia

Comandante, en su raya

Hay Cadáveres"

[ENG] "In the necessity for this absence

In what underlines that speech

In your godly presence

Commander, in your line

There are Corpses" (2002: 457458) 
A "Baroque of the trenches" which used lyrical speech to highlight the conditions for the emergence of the political in post-dictatorial times: that is, the collapse of the unequivocal division between public and private, the macropolitics and micropolitics which had been dominant in the early 1970s. That is why the corpses not only represent those who died from repression but also the shadow of death that dwells in everything, even in details, in the tiniest or the most imperceptible things (and that is another of the poem's baroque characteristics).

I mention Perlongher's "Corpses" because I think that in the late 1970s it was the testimony to a discontinuity about corpses in the period that began in the second half of the 20th century. The immanence that is produced in the "there are" or, if we prefer to say it using the terminology of two philosophers whom Perlongher admired (in fact, he met one of them personally and interviewed him): a plane of immanence. I am obviously referring to Deleuze and Guattari and the idea that "Corpses" was written at a time when the plane of transcendence (not transcendental) above which the corpse had been placed in the time that preceded it, was now blocked. A historical journey of redemption or general epiphany cannot be glimpsed.

This plane of immanence demands something else: a hollow body (like the one in the film Dark River) to see how to give it a meaning. But unlike what happened in the 1950s, when corpses were floating enigmas, medical science and anthropology began to examine them precisely from their immanence. The age of the immortality of corpses in images was succeeded by one in which corpses talk, they carry within themselves the signs and footprints of their own history. It is the forensic turn that treats the dead body like an archive. "The body has become the materiality of a crime, an archive of death. The study of corpses also exists in history to document mass violence and genocides: the forensic turn didn't only happen on TV shows", as Ivan Jablonka writes in Laëtitia ou la fin des hommes (2017).

Survival operates in this new stage in another way: thanks to medicalscientific knowledge, we can know many things about that person. The body contains information and that, in the context of the investigation of the desaparecidos under state terrorism, takes on the nature of a prodigy?

In the films of that time, those made after Albertina Carri's The Blonds (Los rubios, 2003), the corpse becomes a paradoxical figure: since it's desaparecido, its identity is stripped of all corporality and faciality, and therefore the search is carried out in the remains of mass graves. This enables us to verify kinship and at the same time to show its limits: blood ties are proven to be insufficient for changes in families after the dictatorships. Once again, The Blonds enables us to think about this question. In one scene, Albertina and her double (played by Analía Couceyro) go to the National Bank of Genetic Data for a DNA analysis. While the director searches for information to find out where her parents are buried, the actress dramatizes the ghostly nature of the search: the bond with one's parents is not only a matter of blood, it is also an affective one. Albertina and Couceyro, the director and the actress, enter the world of biopolitics, but they don't intend to support it by searching for the DNA of a personless identity in the State. Quite the contrary, what they're doing is undermining it: on one hand, because they separate the biological archive from the assumption of guilt (if the biopolitical archive assumes that we are potential criminals or culprits, then human rights assumes that each of the 
persons examined is a potential victim); on the other hand, because in that fictionalization they are destroying the pre-eminence of blood above affection and the idea of family is completely broken (blood and affection are on the same level, in contiguity: both the director and the actress give blood). In this sequence, we see the blood being extracted and the sheet of a face that is actually a skull, because genetic memory survives death. But in the narrative logic of the film, that skull is both a sheet of medical knowledge and a baroque emblem which, according to the tone of The Blonds, travels between frivolity (vanitas) and mortuary melancholy.

We return to the Baroque and modern allegory, though now stripped of the perspective of transcendence that it possessed in the historical form of the Baroque. The return of the Baroque style is disturbing. In its iconology, death is symbolized by a skull. The skull is not a corpse, it is death itself, which is used for melancholic meditation. The image is deprived of faces and therefore of identity. With the desaparecidos and genetic analysis a paradox occurs: the dead person is not recognized by their features but by the information they contain. The skull acquires a proper name ${ }^{8}$.

However, information (which, as
Benjamin said, imposed itself onto the narration) does not circulate without any interpretation or manipulation. The last famous Argentinian corpse (the district attorney Alberto Nisman, who died in 2015) has said a lot of things since it appeared lifeless in the bathroom of his apartment. Since then, specialists have not agreed on whether he committed suicide, or if he was murdered. Though everything seemed to indicate that there were too many interests at stake to assume that he was murdered, the corpse has not stopped talking since then, and it has done so by asserting or refuting all the hypotheses available. A new state of corpse appears when scientific information and political ideology fight over what it means and want to make it talk. In the new corpses, information replaces sacralization.

Even the most emptied, most anonymous, most destroyed corpse contains information and potential identity recognition. With only a strand of hair or a tiny part of the body, the DNA can be determined. This opens up a new phase in which the falling corpse begins to speak after death. The traditional separation between image and corpse collapses, because it can no longer rest in peace. It is important that it's there to tell us its story.

Translated by Daniela Torres Montenegro (See original text at the end of the journal)

1/ The number has been disputed and it is true that it does not reach 30,000 . But human rights movements decided to keep this figure which was established during the initial reports, when it was still impossible to measure the scale of the massacre. We must also consider the fact that the difference between the figures precisely expresses the uncountable; what can't be counted exactly, and which is too much. On protest marches, they generally use passport-sized photos that the desaparecidos took for their IDs, but which have been greatly enlarged.

2/ See the image of Che Guevara's body an hour and twenty minutes into the version of The Hour of the Furnaces (La hora de los hornos) (https://www.youtube.com/ 
watch?V=X_--jUxpjrQ [access: September 15th 2019]). This passage has been widely disputed because it was added to a posterior version of the first one circulated.

3/ Videla's speech where he robs the desaparecidos of their existence and hurls them beyond life and death: https://www.youtube.com/watch?v=ASMPYgOYueU [access: September 15th 2019].

4/ A 2012 version which shows how the song has endured can be heard on YouTube, sung by children from the Peronist group La Cámpora: https://www.youtube.com/ watch?v=AgOSilufkew [access: September 15th 2019].

5/ Apparently it was the Loggia P-2 that found the body. There is a famous fictionalization of Eva Perón's kidnapping in Rodolfo Walsh's short story “That Woman”, included in his book Los oficios terrestres.

6/ The filmography linked with Evita is much more extensive (apart from the films in which she herself was an actress); I refer only to the ones that have the kidnapping of the corpse as their main subject.

7/ I say "prodigy" because when the Grandmothers of the Plaza de Mayo began the search for their grandchildren and the children of desaparecidos, DNA analyses and expertise in genetic information archives weren't available yet. Initially, the search was based on written documents that were left in hospitals or other state institutions, as well as oral testimonies. DNA analysis changed the conditions of this search and provided them with a unique, accurate tool for determining kinship and filiations.

8/ Of course, there are other ways of identifying a skeleton. For example, by its teeth.

\section{Bibliography}

BENJAMIN, Walter (1998). The origin of German tragic drama. London and New York: Verso.

ELOY, M. Tomás (1995). Santa Evita. Buenos Aires: Editorial Planeta.

JABLONKA, Ivan (2017). Laëtitia o el fin de los hombres. Barcelona: Anagrama.

PEIRCE, Charles Sanders (1955). Logic as semiotic: The theory of signs. PIERCE, Charles Sanders and BUCHLER, Justus (ed.), Philosophical writings of Peirce (pp. 98-119). New York: Dover.

PERLONGHER, Néstor (2002). Cadáveres. NOUZEILLES, Gabriela; MONTALDO, Graciela (eds.), The Argentina reader: History, culture, politics (pp. 457-464). Durham and London: Duke University Press.

WALSH, Rodolfo

(1957). Operación masacre. Buenos Aires: Ediciones Sigla. (1965). Los oficios terrestres. Buenos Aires: Editorial Jorge Alvárez.

How to quote AGUILAR, Gonzalo (2019). Notes on some Argentinian corpses. Comparative Cinema, Vol. VII, No. 13, pp. 39-46. DOI: 10.31009/ cc.2019.v7.i13.03 


\section{Aguilar}

\section{Apuntes sobre algunos cadáveres argentinos}

El cine participa de la tradición de los ritos de evocación de los muertos que son también de separación de sus cadáveres. Una vez que la imagen se forma, el cadáver puede ser enterrado. A veces esta imagen es una lápida, otras una máscara mortuoria o una foto. El cine proporcionó una nueva posibilidad: la filmación del cadáver o el registro de cuando estaba vivo. De este modo, la fotografía y el cine han sido los dos instrumentos de inmortalización (embalsamamiento) más poderosos del siglo XX. El presente artículo indaga sobre los cadáveres inmanentes y trascendentes de la historia argentina: Evita Perón, los desaparecidos de la última dictadura militar, o Pedro Eugenio Aramburu (expresidente de facto que derrocó a Perón en 1955 y fue asesinado por la organización guerrillera de Montoneros), entre otros. A partir de las representaciones cinematográficas que evocan (con mayor o menor literalidad) a estos cadáveres y las expresiones populares que los acompañaron (cantos militantes, expresiones coloquiales, etc.), este texto se pregunta sobre el pasaje de un cadáver, en tanto tal, a su consagración como imagen del pueblo.

Palabras Clave

CADÁVER

REPRESENTACIÓN

CULTURA POPULAR

ARGENTINA

HISTORIA DEL CINE

DESAPARECIDOS

Fecha de recepción: 10/07/2018

Fecha de aceptación: 06/05/2019

Gonzalo Aguilar (Buenos Aires, 1964). Profesor de Literatura Brasileña y Portuguesa en la Universidad de Buenos Aires e investigador del Consejo Nacional de Investigaciones Científicas y Técnicas (CONICET). Dirige la maestría en Literaturas de América Latina de la Universidad Nacional de San Martín y ha sido profesor visitante en Stanford University, en Harvard University y en la Universidade de São Paulo. En 2005 recibió la beca Guggenheim. Escribió en colaboración El cine de Leonardo Favio (1993) y Borges va al cine (2010). Es autor, entre otros, de los libros Poesía concreta brasileña (2003); Otros mundos. Un ensayo sobre el nuevo cine argentino (2006); Episodios cosmopolitas en la cultura argentina (2009); Más allá del pueblo. Imágenes, indicios y políticas del cine (2015). 
¿Qué es la muerte para toda nuestra generación cinematográfica, que se sumió en las cinematecas, sino el efecto que hacen los cadáveres al caer en el cine?

Serge Daney

\section{Indicios}

Desde sus orígenes, el cine tuvo que ver con la muerte 0 , mejor, con los muertos-vivos. En tiempos antiguos existieron ritos que evocaron a los muertos mediante imágenes (máscaras, pinturas, disfraces, momias) y el cine es, en cierto modo, un momento culminante de esa tradición. André Bazin lo expuso con una metáfora: la imagen cinematográfica es como un embalsamamiento. Aunque el carácter mágico pueda afirmarse de muchas imágenes a lo largo de la historia, en el cine adquiere un carácter indicial y fantasmal perturbadoramente real. A diferencia de los otros procedimientos mencionados (máscaras, pinturas, disfraces, momias) solo el cine nos entrega registros de un cuerpo vivo en movimiento. Bazin habla de «embalsamamiento de la realidad» y cuando emplea el sudario de Jesús como símil del aparato creado por los Lumière apela al carácter sacro de la imagen, aún en tiempos de desencanto y modernidad. La apariencia de la vida de los muertos quedaba consignada en la pantalla. De ahí que uno de los primeros mitos del cine sea Drácula, un muerto vivo que nos chupa la sangre.

La novedad radical del cine, entonces, es su carácter de indicio en movimiento que, del mismo modo que la fotografía, "ha sido producido -en palabras de Peirce- bajo circunstancias tales que estaban físicamente forzadas a corresponder punto por punto con la naturaleza» (PEIRCE, 2005).

El cine participa de la tradición de los ritos de evocación de los muertos que son también de separación de sus cadáveres. Una vez que la imagen se forma, el cadáver puede ser enterra- do. A veces esta imagen es una lápida, otras una máscara mortuoria o una foto. El cine proporcionó una nueva posibilidad: la filmación del cadáver o el registro de cuando estaba vivo. De este modo, la fotografía y el cine han sido los dos instrumentos de inmortalización (embalsamamiento) más poderosos del siglo XX.

\section{Cadáveres trascendentes}

Escribe Walter Benjamin en El origen del drama barroco alemán que "contemplada desde la muerte, la vida solo consiste en la producción del cadáver» (BENJAMIN, 1990: 214). Sin embargo, es posible que este cadáver sobreviva, mistificado o con una presencia más potente que la de los vivos. En la historia argentina, son innumerables los cadáveres que han perdurado. Nos acompañan en imágenes que los muestran en su momento de esplendor (o sencillamente vivos) y los hacen persistir en su carácter sagrado o reencantado. Eva Perón, el Che Guevara, las fotos de los rostros que representan a los 30.000 desaparecidos $^{1}$. Las frases emblemáticas dan cuenta del poder de estos muertos: "Hasta la victoria siempre», "divina presencia», "Yo sé que ustedes recogerán mi nombre y lo llevarán como bandera a la victoria", "con vida los llevaron, con vida los queremos". Son cadáveres que imponen un plano de trascendencia. Son intentos de borrar la frontera entre la vida y la muerte o de impugnar lo vivo como no suficientemente vivo si no tiene esa capacidad de entrega y rebeldía. Ya no la vida contemplada desde el cadáver -en palabras de Benjamin- sino desde la Revolución y su finalidad histórica en una epifanía generalizada. Son los cuerpos de la comunidad, los cuerpos que dejaron de ser cadáveres para sobrevivir en las imágenes, por siempre.

En el caso del Che Guevara, su cadáver acostado en una camilla en Bolivia, fue asociado con la figura de un Cristo y 
recorrió el mundo. La hora de los hornos (Fernando E. Solanas y Octavio Getino, 1968) utilizó esa imagen como un modo de alentar a los movimientos de liberación: la muerte del revolucionario no era el testimonio de una derrota sino un mojón más en la lucha ${ }^{2}$. La rostrificación de la figura del revolucionario logró superar la muerte y erigirse como una figura emblemática de las luchas que se desarrollaron desde su muerte. En el caso de los desaparecidos, en cambio, la rostrificación es imposible y se multiplica en las pancartas que se llevan en las marchas. Frente a cualquier política de inmortalización, los militares habían implementado una estrategia que impedía la figuración ${ }^{3}$. ¿Qué hacer, entonces, con los cadáveres?

En la Argentina, el peronismo -en cuanto movimiento que representa con más contundencia al pueblo y lo popular- llevó a cabo una política consistente para dotar a ciertos cadáveres de trascendencia. Tanto en el plano estatal, cuando fueron gobierno entre 1946 y 1955, como en el campo de la resistencia, una vez que el gobierno cayó en 1955. En su libro testimonial Operación masacre, de 1957, Rodolfo Walsh escribió a propósito de los fusilamientos que hizo el gobierno dictatorial de la autodenominada Revolución Libertadora en Tristán Suárez: "Hay un fusilado que vive». En la adaptación fílmica que se hizo en 1973, este "fusilado" abre el filme. Su estatuto paradójico cumple con todas las aspiraciones de la resistencia peronista: oposición al poder, prueba de la represión estatal, fuerza de la lucha popular, opción entre patria o muerte (es decir, muerte por la patria es vida). La contraparte de este cadáver es Pedro Eugenio Aramburu, uno de los protagonistas clave en la caída de Perón y responsable de los fusilamientos. Un cántico popular que se viralizó a principios de los setenta, después de que fuera fusilado por la organización guerrillera Montoneros, muestra claramente lo que es un cadáver solitario, desacralizado o desencantado frente al retorno de la muerte de los líderes o luchadores populares:

«Con los huesos de Aramburu

Vamo'a hacer una escalera

$\mathrm{Pa}$ que baje del cielo

Nuestra Evita Montonera»

La historia del cadáver de Eva Perón es conocida: muere en 1952 y es embalsamada con una técnica novedosa por el Doctor Pedro Ara. Después del golpe de Estado de 1955, el cadáver es secuestrado y comienza un periplo por diversas oficinas militares hasta que finalmente los secuestradores la llevan clandestinamente a Italia. A principios de los años setenta, el cadáver es recuperado. Lo encuentran tajeado y ultrajado ${ }^{5}$. El cuento "Esa mujer» de Rodolfo Walsh (1965), la novela Santa Evita de Tomás Eloy Martínez (1995) y las películas Evita la tumba sin paz (Tristan Bauer, 1997), Eva no duerme (Pablo Agüero, 2017), Eva de la Argentina (María Seoane, 2011) giran alrededor del secuestro del cadáver ${ }^{6}$.

¿Por qué esa saña con el cadáver de Evita? Porque no estaba totalmente muerta, porque podía regresar en cualquier momento como un espectro que podía derribar al gobierno militar. La técnica de embalsamamiento del peronismo era una política de inmortalidad y, encarnada en el cuerpo de Evita, había tenido éxito. Había extraído al cuerpo del ciclo orgánico y lo había convertido en un mito de culto. Pero era tan poderoso el cadáver embalsamado de Evita, que cuando el peronismo fue derribado por un golpe militar, el cadáver fue secuestrado, ultrajado y escondido.

\section{Embalsamamiento}

Eva Perón murió el 26 de junio de 1952. Como decía el mensaje oficial que se transmitía por la radio y por la 
flamante televisión: «a las 20:25 Eva

Perón, jefa espiritual de la Nación, pasó a la inmortalidad». La política de embalsamamiento, es decir de inmortalización, es inmediata. Sin embargo, no es la única estrategia que se puede atribuir al peronismo. Poco antes de la muerte de Evita, el 3 de junio de ese mismo año, se estrenó una de las películas que se convertiría con el tiempo en uno de los clásicos del cine argentino: Las aguas bajan turbias de Hugo del Carril (1952). Reconocido militante del movimiento (como cantante le dio su voz a la "Marcha peronista»), su película fue muy resistida en algunos sectores del gobierno, sobre todo por el poderoso Raúl Alejandro Apold, de la Subsecretaría de Prensa y Difusión. Del Carril tuvo que hacer algunas modificaciones para que fuera aceptada $y$, una vez estrenada, careció del apoyo oficial. Se ha hablado a menudo de una enemistad personal entre Apold y Hugo del Carril, pero sin duda los conflictos con el filme tenían otras motivaciones. Mezcla de melodrama, prédica política y neorrealismo, la película se alejaba del cine dominante que giraba alrededor de géneros convencionales e historias que evitaban las referencias directas. El hecho de que estuviera basada en la novela de un escritor comunista (Alfredo Varela) que estaba preso era otra razón para las presiones. De hecho, Varela no figura en los créditos. Existe otra razón que seguramente no pesó de un modo conciente pero el modo en que los cadáveres aparecen en Las aguas bajan turbias marca una diferencia con el discurso dominante y su política de inmortalización. Frente al embalsamamiento, Las aguas bajan turbias exhibe cadáveres vacíos.

La historia comienza con una voz en off -la misma de los noticieros oficiales de la época- que nos advierte que lo que se va a contar sucedió «hace unos años, unos pocos años»: la imagen pasa entonces de los bellos paisajes de los esteros mesopotámicos en lo que pare- ce un corto de promoción turística a los cadáveres que arrastra el río y que vienen del infierno verde de los yerbatales. A diferencia de los cadáveres embalsamados que tienen los ojos cerrados y la piel tersa, los cuerpos que bajan del río en Las aguas bajan turbias tienen los ojos vaciados y la piel putrefacta. No configuran un monumento y son anónimos («sin rostros, sin nombre, sin familia» dice el narrador), no están quietos e inalterables sino en movimiento con el flujo del río y en descomposición. Son cadáveres orgánicos, es decir, abiertos al tiempo. Cadáveres mortales. Más cerca de Heráclito que de Parménides, son "cadáveres boyando».

Lo más importante de esta confrontación (cadáver embalsamado/cadáver en descomposición) es que mientras el primero supone una política de la inmortalidad que, por contigüidad, supone una perpetuación del poder (como en el caso de Lenin, el cuerpo embalsamado está ahí para que lo adoren futuras generaciones), el segundo supone una lucha permanente, un trabajo por dotar a esos cadáveres de sentido y darles una dirección determinada. Es lo que sucede en la película en el momento en que los obreros de los yerbatales descubren la fuerza de la unidad sindical y se rebelan contra los patrones ("la sangre fecunda como una semilla», se escucha al final de la película). En pleno gobierno peronista, Hugo del Carril opone a las políticas estatales de inmortalización, la existencia de cadáveres sin descanso, sin lecho de muerte, que necesitan ser redimidos.

No es casual que la mayor exigencia del gobierno peronista a una película peronista fue que agregara un prólogo en el que aclaraba que lo de los cadáveres era algo que sucedía antes, «hace unos años, unos pocos años». De todos modos, esos cadáveres no dejan de pasar, de boyar o de hundirse. La política del embalsamamiento imagina un fuera de tiempo que la historia viene una y otra vez a frustrar. 


\section{Inmanencia e inminencia}

El carácter indicial de la imagen también existe en la lengua. Según Charles Sanders Peirce, «un nombre propio, demostrativo personal o pronombre relativo" son índices. Pero ¿qué sucede cuando, como no es extraño en América Latina, ese cadáver carece de nombre propio? ¿Qué pasa cuando se trata de un cadáver despojado, despedazado, escamoteado o-para usar un término de gran significación histórica-desaparecido? ¿Qué es lo que pasa, en definitiva, cuando no puede usarse el nombre propio o designar un cuerpo que está ahí? Néstor Perlongher ha ensayado una respuesta poética en su texto «Cadáveres» mediante un verbo: "hay».

«En el campo

En el campo

En la casa

En la caza

Ahí

Hay Cadáveres

En el decaer de esta escritura

En el borroneo de esas inscripciones

En el difuminar de estas leyendas

En las conversaciones de lesbianas que se muestran la marca de la liga,

En ese puño elástico,

Hay Cadáveres»

El «hay» es la presencia que empuja desde abajo, la fuerza que se impone, el cuerpo que, pese a estar muerto, está ahí, imperturbable y perturbándonos. Poema escrito entre el 82 y el 83 , «Cadáveres» se publicó en el primer número de la revista Diario de poesía (abril de 1984), en el contexto de la discusión sobre el neobarroco o, en su versión rioplatense, el neobarroso. La frase de
Benjamin se vuelve reveladora: el cadáver perdió toda posibilidad de redención, la «divina presencia» solo retorna como ironía o insuficiencia.

«En lo preciso de esta ausencia En lo que raya esa palabra

En su divina presencia

Comandante, en su raya

Hay Cadáveres»

Un «barroco de trincheras» que señalaba, con la palabra poética, las condiciones de emergencia de lo político en los tiempos de la posdictadura; esto es: el colapso de la división tajante entre lo público y lo privado, la macropolítica y la micropolítica que había sido dominante a principios de los setenta. De ahí que los cadáveres no sean solamente los muertos de la represión sino la sombra de muerte que anida en todo, aun en los detalles, en lo más diminuto e imperceptible (y este es otro rasgo barroco del poema).

Traigo a cuento "Cadáveres» de Perlongher porque me parece que es, a fines de los setenta, el testimonio de una discontinuidad sobre el cadáver en el periodo que comienza en la segunda mitad del siglo XX. La inmanencia que se produce en el "hay», o, si queremos decirlo con la terminología de dos filósofos a los que Perlongher admiraba (de hecho conoció personalmente a uno de ellos y lo entrevistó), un plano de inmanencia. Obviamente me refiero a Deleuze y a Guattari y a la idea de que "Cadáveres» se escribe en un momento en que está bloqueado el plano de trascendencia (no trascendental) sobre el que se había colocado el cadáver en el tiempo que lo precedió. No se vislumbra un camino histórico de redención o epifanía generalizada.

Este plano de inmanencia exige otra cosa: un cuerpo vaciado -como el de la película Las aguas bajan turbias- para ver cómo dotarlo de sentido. Pero a di- 
ferencia de lo que sucedía en la década del cincuenta donde los cadáveres eran enigmas boyando, la ciencia médica y antropológica comenzó a interrogarlos desde justamente su inmanencia. A la etapa de la inmortalidad de los cadáveres en la imagen le sucedió la de los cadáveres que hablan, que llevan en sí mismos los indicios y las huellas de su propia historia. Se trata del giro forense que trata al cuerpo muerto como un archivo. "El cuerpo se ha convertido en la materialidad de un delito, en un archivo de la muerte. El estudio de los cadáveres también existe en historia para documentar las violencias masivas y los genocidios: el forensic turn (o giro forense) no sólo tuvo lugar en las series de televisión", se lee en Laëtitia o el fin de los hombres de Ivan Jablonka (2017).

La supervivencia opera en esta nueva etapa de otra forma: gracias al conocimiento médico-científico podemos saber muchísimas cosas de esa persona. El cuerpo contiene información y eso, en el contexto de la indagación sobre los desaparecidos durante el terrorismo de Estado, adquiere el carácter de un prodigio?.

En los filmes del periodo, realizados a partir de Los rubios (2003) de Albertina Carri, el cadáver se convierte en una figura paradójica: despojado, al ser "desaparecido", de identidad (de corporalidad y rostreidad), la búsqueda se hace en los restos que hay en las fosas. Esto permite comprobar el parentesco y a la vez mostrar su límite: los lazos de sangre se revelan insuficientes para las mutaciones de la familia posteriores a las dictaduras. Una vez más, Los rubios nos permite pensar esta cuestión. En una de sus escenas, Albertina y su doble (interpretado por Analía Couceyro) se dirigen al Banco Nacional de Datos Genéticos para hacerse el análisis de ADN. Mientras la directora busca la información para saber dónde están enterrados sus padres, la actriz pone en escena el carácter fantasmal de la búsqueda: el lazo con los padres no solo es de orden sanguíneo sino también afectivo. Albertina y Couceyro, la directora y la actriz, entran en la escena biopolítica, pero no lo hacen para sostenerla buscando en el Estado la identidad sin persona del ADN. Muy por el contrario, lo que están haciendo es minarla: por un lado, porque separan el archivo biológico de la suposición de culpabilidad (si el archivo biopolítico nos supone reos o culpables potenciales, los derechos humanos suponen que cada uno de los examinados es una víctima potencial); por otro, porque en esa ficcionalización se destruye la preeminencia de la sangre por sobre los afectos y la idea de familia se quiebra por completo (sangre y afectos están en un mismo nivel, en contigüidad: se sacan sangre la directora y la actriz). En la secuencia, vemos la extracción de sangre y la lámina de un rostro que es en realidad una calavera, porque la memoria genética sobrevive a la muerte. Pero, en la lógica narrativa del filme, esa calavera es tanto una lámina del saber médico como un emblema barroco que, acorde con el tono de Los rubios, transita entre la frivolidad (la vanitas) y la melancolía mortuoria.

Volvemos al barroco y a la alegoría moderna pero ahora despojada del horizonte de trascendencia que tuvo en el barroco histórico. El retorno del barroco es perturbador. En su iconología la muerte se simboliza con una calavera. La calavera no es un cadáver sino que es la muerte misma que se hace presente para la meditación melancólica. La imagen está destituida de rostros y por lo tanto de identidad. Con los desaparecidos y los análisis genéticos se produce una paradoja: el muerto no se reconoce por sus rasgos sino por la información que contiene. La calavera adquiere nombre propio ${ }^{8}$.

Sin embargo, la información (que, como decía Benjamin, se impuso a la narración) no circula sin interpretaciones y manipulaciones. El último cadáver argentino célebre -el fiscal Alberto 
Nisman, muerto en 2015- ha dicho muchas cosas desde que apareció sin vida en el baño de su departamento. Desde entonces, los peritos no se han puesto de acuerdo sobre si se suicidó o fue asesinado. Aunque todo parecía indicar que había demasiados intereses en juego para suponer que lo mataron, el cadáver desde entonces no ha dejado de hablar y lo ha hecho afirmando o refutando todas las hipótesis disponibles. Un nuevo estadio del cadáver aparece cuando la información científica y la ideología política se disputan sobre sus sentidos y quieren hacerlo hablar. En los nuevos cadáveres, la informa- ción destituye a la sacralización.

Aún el cadáver más vaciado, más anónimo, más destruido, contiene información y potencial reconocimiento identitario. Con solo un cabello o una parte ínfima del cuerpo puede determinarse el ADN. Se abre así una nueva etapa en la que el cadáver que cae, comienza a hablar después de muerto. La separación tradicional entre imagen y cadáver colapsa, porque éste ya no podrá descansar en paz. Es importante que esté ahí para que nos diga cuál es su historia.

1/ Se ha discutido el número y es cierto que no asciende a 30.000. Pero los movimientos de derechos humanos se decidieron a mantener ese número que se decidió en las primeras denuncias, cuando todavía era imposible calibrar las dimensiones de la masacre. También cabe pensar que la diferencia entre los números habla justamente de lo innumerable, de lo que no se puede contar de un modo exacto, de lo que resulta demasiado. En las marchas, por lo general se usa la foto-carnet que los desaparecidos se sacaron para los documentos de identidad pero en grandes dimensiones.

2/ Ver la imagen del cadáver del Che Guevara a la hora y veinte minutos de la versión de La hora de los hornos (https://www.youtube.com/watch?v=X_--jUxpjrQ [acceso: 15 de septiembre de 2019]). Se ha discutido mucho este pasaje porque fue agregado en una versión posterior a la primera que circuló.

3/ Puede verse el discurso de Videla donde despoja de existencia a los desaparecidos y los arroja más allá de la muerte y de la vida: https://www.youtube.com/watch?v=ASMPYgOYueU [acceso: 15 de septiembre de 2019].

4/ Una versión de 2012, lo que muestra la persistencia del cántico, puede escucharse en YouTube cantada por muchachos de la agrupación peronista La Cámpora: https://www.youtube.com/watch?v=AgOSilufkew [acceso: 15 de septiembre de 2019].

5/ Al parecer la encargada del hallazgo del cadáver fue la Logia P-2. Hay una ficcionalización célebre del secuestro de Eva Perón en el cuento de Rodolfo Walsh, «Esa mujer», incluido en su libro Los oficios terrestres.

6/ La filmografía relacionada con Evita es mucho más extensa (además de las películas en las que ella misma hizo de actriz), me refiero solamente a las que tienen como tema central el secuestro del cadáver.

7/ Hablo de prodigio porque cuando las Abuelas de Plaza de Mayo comenzaron la búsqueda de sus nietos e hijos de desaparecidos no se contaba todavía con los análisis de ADN y la formación de archivos de información genética. En el primer momento la búsqueda se basaba en documentos escritos que pudieron haber quedado en hospitales u otras dependencias estatales además de testimonios orales. El análisis por ADN cambió las condiciones de esta búsqueda y las dotó de una herramienta única y certera para determinar los parentescos y las filiaciones.

8/ Por supuesto que hay otras maneras de dotar de identidad a un esqueleto. Por ejemplo, por las piezas dentarias. Pero el análisis de ADN instaura un nuevo tipo de reconocimiento. 
BENJAMIN, Walter (1990). El origen del drama barroco alemán. Madrid: Taurus.

ELOY, M. Tomás (1995). Santa Evita. Buenos Aires: Editorial Planeta.

JABLONKA, Ivan (2017). Laëtitia o el fin de los hombres. Barcelona: Anagrama.

PEIRCE, Charles Sanders (2005). El icono, el índice y el símbolo. Recuperado de: http://www.unav.es/gep/lconolndiceSimbolo.html [acceso: 13 de junio de 2019]

PERLONGHER, Néstor (1984). Cadáveres. Diario de poesía, abril de 1984. WALSH, Rodolfo

(1957). Operación masacre. Buenos Aires: Ediciones Sigla.

(1965). Los oficios terrestres. Buenos Aires: Editorial Jorge Alvárez. 